\title{
Teaching Creative Writing in Special Collections
}

While enrollments are in a downward trend in humanities departments across the board and in English departments in particular, ${ }^{1}$ creative writing has emerged as an area of explosive growth: creative writing enrollments and majors are up, and undergraduate and graduate student demand is high. The impact of this shift on English departments from the traditional focus on literature to creative writing has significant ramifications for university professors and librarians. According to a recent report by the Association of Departments of English (ADE), "The structural visibility of creative writing suggests its considerable importance for the English major-and the growth potential of creative writing does not appear to be exhausted." The ADE recommends "that departments give continued attention to building enrollments in creative writing and to its fruitful connections and contributions to students' education in literary and writing studies." ${ }^{3}$ Special collections librarians involved in integrated course instruction with English departments should take note of the ADE report and its recommendation that English departments across the country continue to direct their pedagogical resources to creative writing. What are we doing to serve this growing population of students and how are we adapting our outreach to reflect changing English department enrollments and instruction needs? With David Pavelich, I am in agreement that "For special collections to remain a vibrant and visible presence on university and college campuses, special collections librarians need to reach out to developing user groups" like creative writing students. ${ }^{4}$

1. Academy of American Arts and Sciences, "Bachelor's Degrees in the Humanities," Humanities Indicators (May 2017), available online at https: / / humanitiesindicators.org/content/indicatordoc. aspx?i=34 [accessed 3 June 2019].

2. Association of Departments of English Ad Hoc Committee on the English Major, "A Changing Major: The Report of the 2016-17 ADE Ad Hoc Committee on the English Major" (July 18, 2018), 19, available online at https: / / www.ade.mla.org/Resources/Reports-and-Other-Resources/A-ChangingMajor-The-Report-of-the-2016-17-ADE-Ad-Hoc-Committee-on-the-English-Major [accessed 31 May 2019].

3. "A Changing Major," 23.

4. David Pavelich, "Lighting Fires in Creative Minds: Teaching Creative Writing in Special Collections," College \& Research Libraries News 71, no. 6 (2010), available online at https:// crln.acrl.org/index. $\mathrm{php} /$ crlnews/article/view/8386/8560 [accessed 31 May 2019].

๑ 2019 by Alison Fraser (CC BY-NC [https://creativecommons.org/licenses/by-nc/4.0/]). 
Integrated undergraduate course instruction in special collections has emerged as an important area of outreach in recent years, as evidenced by numerous articles in publications like RBM: A Journal of Rare Books, Manuscripts, and Cultural Heritage and The American Archivist, ${ }^{5}$ edited collections like Past or Portal? Enhancing Undergraduate Learning Through Special Collections, and programs like Dartmouth College's Librarians Active Learning Institute-Archives and Special Collections track and the ACRL Rare Books and Manuscripts subgroup on teaching and instruction, which produces a lively schedule of webinars, a newsletter, and social media discussions on teaching with primary sources. These platforms underscore how, through integrated course instruction, students' perceptions of "rare editions and the ability to access them" changes, with dividends paid to the student, the instructor, and the librarian. ${ }^{6}$

Despite the robust discussion around integrated course instruction in special collections, relatively little attention has been paid to the possibilities of teaching creative writing. This is due in part to creative writing classes often following a workshop model that differs in pedagogical approach to traditional literature classes: the creative writing course's major project is typically a portfolio of original work, rather than a research paper. But rather than being an impediment, the workshop model opens up new opportunities for affective, creative, and cognitive engagement with special collections. In creative writing workshops, students' main activity through the semester is to create their own work and critique their classmates', and some supplemental reading is often incorporated since "any writing act involves a conversation, with other writers, living and dead." Creative writing students are thus already in the mindset that their creative output drives the direction of the course, making them well suited to sessions in special collections. David Pavelich's "Lighting Fires in Creative Minds" is one of the only articles to offer strategies geared specifically toward creative writing students. Pavelich briefly describes the following strategies: historical fiction (which asks students to mine the archives for historical context), editorial interventions (where students examine the editorial files for Flood Editions), drafts (where students examine different published versions of poems), versions (where students examine the first and last editions of Leaves of

5. See, for example, articles from the past four years: Courtney Jacobs, Marcia McIntosh, and Kevin M. O’Sullivan, "Making Book History: Engaging Maker Culture and 3D Technologies to Extend Bibliographical Pedagogy," RBM 19, no. 1 (Spring 2018); Melissa McCullan and Joanna Cobley, "Lessons in Ephemera: Teaching and Learning through Cultural Heritage Collections," RBM 18, no. 2 (Fall 2017); and Silvia Vong, "A Constructivist Approach for Introducing Undergraduate Students to Special Collections and Archival Research," RBM 17, no. 2 (Fall 2016). In archives, the discussion is equally engaged: Rachel M. Grove Rohrbaugh, "Teaching with Primary Sources," The American Archivist 80, no. 2 (Fall/Winter 2017): 462-66; and Christy Fic, "Working as an Embedded Archivist in an Undergraduate Course: Transforming Students into Scholars through an Archival Workshop Series," The American Archivist 81, no. 2 (Fall/Winter 2018): 290-309.

6. Ryan Prendergast and Kristen Totleben, "Course Design, Images, and the Class-Curated Exhibit," RBM 19, no. 2 (Fall 2018): 149.

7. Peter Carpenter, "Creative Writing Workshops: A Main Course (2)," Use of English 70, no. 1 (Autumn 2018): 12 . 
Grass), and self-publishing and alternative book forms (where students learn about the history of the chapbook). While several of these strategies are similar to those I discuss below, our approaches differ. For instance, in discussing an instruction session he ran on alternative book forms, Pavelich describes a class organized around lecture- "I discussed the history of the pamphlet... We also talked about the tradition of self-publication"-without describing active learning techniques to engage students with the subject, such as those I describe below. As a brief article, it does not discuss in depth how these classes were taught nor give practical strategies for instruction. To Pavelich, "Creative writing programs offer special collections librarians a unique (and fun) outreach and instruction opportunity," and at the same time, "special collections libraries have much to offer creative writing programs." In The Special Collections Handbook, Alison Cullingford agrees, writing, "Special Collections are full of materials that could inspire a creative response in students," and "New or unexpected formats [usually only found in special collections] such as ephemera, private press and artists' books can help enliven learning for students." Presenting on the UK Group of Literary Archives and Manuscripts, Jessica Gardner reports, "At Manchester, Exeter, Oxford and Leeds universities, there is [a] rise in interest in the potential of literary manuscripts to help teach creative writing, by using the drafts of established writers to demonstrate the hard slog and craft of composition and to inspire new works." ${ }^{10}$ All three authors agree that the unique resources of special collections can inspire creative writing students by introducing them to otherwise unavailable materials such as evidence of the creative process in the form of manuscript drafts, nonstandard book objects, and alternative book publishing strategies. Within special collections, creative writing students can initiate conversations with writers, past and present.

Drawing from my experience as a creative writing instructor in an English department as well as a course-integrated librarian in special collections, I continue this conversation by outlining three strategies for engaging undergraduate creative writing students in special collections through interacting with chapbooks, noncodex book objects, and manuscripts. The active learning techniques I describe below guide students to find creative inspiration, an appreciation for book history that enhances their understanding of publication, and increased primary source literacy in creative writing classes that make use of special collections libraries. By encoun-

8. David Pavelich, "Lighting Fires in Creative Minds: Teaching Creative Writing in Special Collections," College \& Research Libraries News 71, no. 6 (2010), available online at https:// crln.acrl.org/index. $\mathrm{php} /$ crlnews/article/view/8386/8560 [accessed 31 May 2019].

9. Alison Cullingford, The Special Collections Handbook, 2nd ed. (London, UK: Facet Publishing, 2016), 204.

10. Jessica Gardner, "Manuscripts Matter: Collecting Modern Literary Archives: A Conference at the British Library, 19-20 October 2006" (2006), 2, available online at https:/ / www.webarchive.org.uk/ wayback/archive/20091016204357/https:/ / www.literary.org.uk/pdfs/Jessica_Gardner.pdf [accessed 31 May 2019]. 
tering diverse poetic materials from chapbooks (which range from fine press artists' books to DIY publications) to noncodex books (which disrupt any preconceived understanding of the concept of the book) and manuscripts (which demonstrate the sometimes messy process of revision), students witness the writing process from different vantage points. Creative writing instructors argue that the workshop needs to move beyond encouraging students to express themselves and "fix" their writing to teaching "writers to engage with the world we all share and consider imaginative writing's ability to illuminate the clash of social forces." ${ }^{11}$ Integrating creative writing workshops with visits to special collections is one way to advance this pedagogy. While my examples will draw from the Poetry Collection of the University Libraries, University at Buffalo, The State University of New York, which is the library of record for 20th- and 21st-century poetry in English, creative writing students will benefit from experiences at special collections libraries less obviously aligned with literary studies.

At the University at Buffalo, Introduction to Creative Writing now fulfills a general education requirement, increasing enrollments and guaranteeing an influx of nonEnglish majors to the department. The English Department also offers advanced workshops in creative writing as well as graduate creative writing courses that support its new Innovative Writing MA program. Consequently, there are more creative writing students now than ever before, and these students represent different levels of familiarity with poetry and interest in the course. Instructors of these courses frequently request one-off sessions in the Poetry Collection, with the general goal of exposing their students to contemporary poetry publications. As I have developed teaching strategies for creative writing students, I have planned instruction sessions so that students gain a wider appreciation of both poetics and book history in addition to an increased awareness of trends in contemporary poetry. These sessions are an important tool for student outreach, as they are frequently the first time students will come into contact with Special Collections during their time at UB.

All of the classes described below are one-shot instruction sessions representing classes between 50 and 90 minutes in length of 10 to 24 students. In planning the session, I ask the instructor which poets they have been reading and make every effort to incorporate materials by these writers; I also emphasize Buffalo-based poets and publications as a way to meet students where they are. I design these classes with the primary goal of affective results, with creative inspiration and cognitive results secondary; my goal is that, in visiting special collections, creative writing students begin to see themselves within a contemporary writing community and as part of a

11. Kate Kostelnik, "Innovative Frameworks and Tested Lore for Teaching Creative Writing to Undergraduates in the Twenty-First Century," Pedagogy 14, no. 3 (Fall 2014): 437. 
larger history of writers. In this way, the creative writing student in special collections becomes a "self-reflective user" who "considers primary sources in the context of their own project as well as their agency in creating new primary sources." 12

\section{Chapbooks}

For Introduction to Creative Writing students, I am often asked to run a "history of chapbooks" session, with the goal of showing students how poets have circulated their poetry throughout the 20th and into the 21st centuries. Chapbooks are an important aspect of a poet's publishing career; many will publish a chapbook before publishing their first book. Chapbooks can be a quick and easy way to distribute poetry. Chapbooks are typically about 15-20 pages in length and stapled or stitched, without bound spines. The relatively familiar form and accessible construction of chapbooks - they are easy for students to create themselves using only a printer and a stapler or needle and thread—makes them particularly suited to introductory classes.

This session is a good warmup to studying book objects, as students get a crash course in 20th-century book history and an introduction to thinking about books as objects. Once they are familiar with this concept, they are more receptive to and think more deeply about noncodex book objects in the collection. For 20th- and 21 st-century poetry chapbooks, I strive to include as many different formats as possible so students are exposed to the range of chapbook production in modern poetry. This includes letterpress, Xerox, and mimeograph printing; saddle-stitched, side-stapled, and even bolted bindings; and commercial publications (like Black Sparrow's chapbook series), artists' books, and homemade DIY publications.

I begin class sessions by providing students with a 10-15-minute orientation to our library and the work we will accomplish during the period. My overview includes a brief introduction to the Poetry Collection and its collection practices, which include collecting first and other bibliographically significant editions, little literary magazines, and other poetry publication ventures; the history and significance of chapbooks, sometimes illustrated with a chapbook from the Rare \& Special Books Collection, such as a 16th-century French political pamphlet; and a summary of the kinds of chapbooks we will be looking at and how we will approach them - and how to handle them. This introduction gives students a basis for individual exploration. Rather than conduct the class as a show-and-tell session, I assign each student or pair of students their own chapbook, which I ask them to study for about 20-25 minutes before sharing their findings with the class.

12. ACRL RBMS-SAA Joint Task Force, "Guidelines for Primary Source Literacy” (Summer 2017), 3, available online at https://www2.archivists.org/groups/saa-acrlrbms-joint-task-force-on-primarysource-literacy/guidelines-for-primary-source-lite-0 [accessed 5 June 2019]. 
Since most students have never considered the book as an object before and have only read for printed text, not material signifiers, I provide them with a worksheet that leads them through a simple exploratory analysis of the physical object. (See the appendix for an example of this worksheet.) In their preliminary exploration, students are asked to describe what they see when the chapbook is closed (students are so used to analyzing text that they often open books without considering the cover, not knowing yet that books should sometimes be judged by their covers). Then they are asked how the chapbook opens (vertically, horizontally, or not at all?), when and where it was published, who wrote it, how many poems are printed in it, and how much it cost. Next, students move on to questions related to materials: what is the chapbook made from or how was it printed (is there anything distinctive or unusual about the materials)? How is it bound together (with staples, string, folds, or something else)? Finally, students are asked to synthesize their observations through a series of analysis questions: how would the experience of reading this chapbook be different from reading a coursepack or textbook? How do they think the form or format of the book changes or contributes to the message of the poem(s)? These questions help students become aware of the interaction between written creative expression and materiality as well as networks of writers and publishers. They also ask students to be reflective of their experiences as students at a university whose course materials are usually presented in textbooks or anthologies. Finally, they provide the launching point for students' own homemade publications. For example, students in one course were encouraged to demonstrate "experimentation and awareness of materiality" in their final projects. According to their professor, "students absorbed a great deal from their trip to the Poetry Collection, creating an array of formally and materially exciting chapbooks," which ranged from paper flowers bound along one petal, a knit sock binding, a book of poems in a homemade box, and a chapbook bound together with repurposed binder clips.

During the final 15-20 minutes of the class, students share their findings with the group, taking ownership over their discoveries as the class expert on their chapbook. I ask them to give a general overview of their chapbook and note anything unusual or surprising about it. These presentations allow students to contribute to the group's understanding of chapbooks and provide a way for me to interject information about the poet, press, or individual chapbook as part of a conversation with the students rather than in a lecture. ${ }^{13}$

Langston Hughes's A New Song is one chapbook that encourages productive discussion during these sessions. Introduced by Michael Gold and with a frontispiece

13. This pedagogical approach reflects the overall trend in archival and rare book instruction from lectures and show-and-tells to hands-on, inquiry-based learning models. See Chris Marino, "Inquirybased Archival Instruction: An Exploratory Study of Affective Impact," The American Archivist 81, no. 2 (Fall/Winter 2018): 484. 
by Joe Jones, it opens up conversations about how a work is framed and how an author is presented, and how these paratexual apparatuses influence the reader. Published in 1938 by the International Workers Order, it also insists on a very specific and important historical context and invites students to think critically about audience. The chapbook (priced at 15 cents) was published to be affordable for working-class readers, with the goal of reaching readers who might not otherwise read poetry, calling upon them to stand up against racial and economic injustice. It opens with Hughes's poem "Let America Be America Again"-which is experiencing a renaissance in popularity given the current political climate-which also allows me to expand this session to a discussion of manuscripts (as the Poetry Collection holds five autograph manuscripts and typescripts of the poem, heavily annotated and edited by Hughes) and the place of poetry in our lives today.

This chapbook activity helps students place poetry within a social context, encouraging them to think of their class itself as a writing community and offering inspiration for potential DIY publications. Held at the beginning or midpoint of the semester, this exercise has the potential to inform the rest of the semester, even if the class does not return to special collections: As one instructor reported, "Encountering the meaningful materiality of the texts from the [Poetry Collection] changed the way [the students] read subsequent texts in the class (for instance, some interesting questions arose about the comparative 'immateriality' of digital poetry) and shaped their own developing creative practices."

\section{Book Objects}

Working with poetry book objects helps students recognize immediately the status of the book as a physical object. The unusual formats found in our Poetry Objects section surprise and delight students, who have never considered the book beyond the codex. These objects challenge what a book is and does-and how it is read. Their form directly relates to their content in a way that is clear to even the most novice literary student, making them ideal objects through which to introduce the basic concepts of book history. Many of the unusual formats are also objects that students can make themselves, giving them agency over their own production.

I started teaching classes devoted to book objects after a professor approached me asking if her class could see noncodex books to use as inspiration for their portfolios. This is now one of the most-requested sessions, in part because it surprises students, disrupts their expectations about what special collections is, and contradicts their assumptions about what a book looks like. These sessions are often playful, opening up the library and the materials to students who might otherwise be closed off. The student projects that came out of the first book object course I taught so impressed their instructor that she rates them as the best in her 30-year 
career, and included a vase of paper flowers where inside each bloom had been written a poem by William Carlos Williams, and a bust whose top opened to reveal a brain made from poems by Lucille Clifton.

Book objects include artists' books as well as nontraditional publications. Books that frequently appear in these sessions include Johanna Drucker's Stochastic Poetix (Granary Press, 2012), a letterpress book with brushed metal covers; Cole Swensen and Karen Randall's The Leyden Jar Project (Propolis Press, 2018), made of an acrylic box with twelve glass jars connected to a microprocessor that plays a different poem depending on how long the jar is touched by the reader; M. NourbeSe Philip's The Book of Un with Undex (Container Press, 2018), a book made from a Rolodex that has been stained with tea and burned in the oven; Cecilia Vicuña's Chanccani Quipu (Granary Books, 2012), made from unspun wool tendrils on a dowel; and Clark Coolidge's On the Slates (Flockophobic Press, 1992), made from a shoe with loose leaves of paper and a dollar bill tucked inside. Periodicals like Look Book, Ferrum Wheel, and Asian American Literary Review are also interesting for students to consider; they include issues made from a View-Master toy, miscellaneous poems and objects housed inside a "pipe-bomb picnic basket," and Tarot cards reimagined for the Asian American experience. All of these objects explore the three-dimensional possibilities of poetry and underscore to students the relevance and excitement of looking at all books, including codices, as objects.

Since many of these items are fragile and require primary handling by staff, these sessions take a more lecture-based approach. However, where possible I pair students with objects and guide them through a similar set of questions as I do with the chapbooks. Students quickly pick up on how clearly playful and irreverent these objects are, and class sessions become very social as students "show and tell" their book objects to their neighbors, excited to share their discoveries right away and one-up each other. I remind students that the books' irreverence is deliberate and can be a critique against several systems - the publishing economy and editorial practices foremost among them-asking them to begin to think critically about the production of the book and the many agents, stakeholders, and biases that were and are inherent aspects of the publishing business.

Tyrone Williams's Trump L'oeil (Hostile Books, 2017) is a wonderful point of engagement for students. Hostile Press is a Buffalo-based collective whose web presence is on Tumblr, the social media platform of choice for many undergraduate students. The edition is made from 52 tissue boxes, each smashed by Williams after he had written poems on the tissues inside. The book is accompanied by a paragraph of paratext, which introduces students to the idea of conceptual poetry and provides assistance in interpreting the work. The paratext is useful in convey- 
ing to students the poet's process and how even something as seemingly simple (and perhaps even as flippant) as a crushed tissue box contains much forethought, revision, and purpose. The work is inspired by the 2016 presidential election, when Williams wanted to address "three interrelated ideas: the nostalgia for a return to the country's childhood when there were 'only' thirteen colonies, the incorporation of the District of Columbia and the territory of Puerto Rico as 'states' within empire (hence fifty-two boxes) and the 'illusion' of three-dimensional space as isomorphic with... 'reality."'14 Although originally Williams had wanted the tissues to be used - in other words, sneezed on - he opted against this route and instead wrote thirteen one-line poems, so the "ephemeral status of the project constitutes a shot across the bow." 15 The form of the book and the process of its creation are integral to its message, Williams explains: "The partial destruction of the tissue boxes represents the 'intrusion' of temporality (I smashed each box with my right foot in my office), that 'fourth dimension called change which undermines every status quo, every 'state,' as such." The purpose of tissues to comfort the sick and the grieving - now repurposed as a book of poetry-underscores Williams's message of the increasing vulnerability of the black male body and becomes part of his mourning process following the election. Students quickly see that they could make a similar poetry object and begin to approach everyday items in a different light: like language, mundane objects take on a special significance within the context of poetry.

Introduction to Creative Writing students respond positively to book objects, which remove any perceived pretentiousness about poetry. The introduction classes are split into fiction and poetry units, and many students dread the point in the semester when they arrive at poetry. A visit such as this one to the Poetry Collection demonstrates the ways in which poetry can be accessible, fun, and surprising. Students continually come away from this class amazed that a book of poems could look like that.

For advanced creative writing classes, I integrate book history via selections from the Rare $\&$ Special Books Collection at UB to show how the idea of the book as an object and work of art has evolved over 550 years. In the most recent advanced creative writing course I taught, the professor wanted me to address contemporary chapbooks and serials, visual art, and noncodex books and assigned her students two chapters from The Companion to Book History, "The Book as Art" by Megan L. Benton and "Some Non-textual Uses of Books" by Rowan Watson. I selected the Rare \& Special Book Collection’s manuscript breviary (ca. 1450), a book of hours

14. This text is included with the book object and is also on the press's website. Tyrone Williams, “Trump L'oeil," Hostile Books (May 19, 2017), available online at https: / / hostilebooks.tumblr.com/ post/160843191070/trump-loeil [accessed 31 May 2019].

15. Williams, "Trump L’oeil." 
(ca. 1502), De Re Militari (1607), Theatrum Botanicum (1640), and the Kelmscott Chaucer on vellum (1896). Obviously these five books cannot come close to giving a comprehensive overview of book history, but they hit on several key points and align with the supplemental reading given to the students while allowing the majority of the class session to be dedicated to an analysis of Poetry Collection materials.

I clustered my selections around three key themes, pairing a book from the Rare \& Special Books Collection with several from the Poetry Collection: book printing and technology; the book as object; and the book as work of art. Once students had made and shared observations about both the rare books and poetry books, I asked them to start drawing connections between the pairings. For example, Theatrum Botanicum was paired with James Walsh's The Arctic Plants of New York City (Granary Press, 2011), a contemporary herbarium and poetry book that celebrates biodiversity and quotidian flora of the urban landscape. De Re Militari was paired with N.H. Pritchard's Eecchhooeess (New York University Press, 1971): students compared and contrasted the inventive military formations made from letters and numbers by creative 17th-century typesetters with Pritchard's concrete poems that at once disrupt the function of word and page layout and refute the assumption that avant-garde experimental writing is pioneered by white authors. By comparing books from the Rare $\&$ Special Books Collection with contemporary publications, students were able to develop an understanding of the historical context of publication and the materiality of creative expression.

\section{Literary Manuscripts}

One of my favorite creative writing sessions to lead involves literary manuscript analysis. Teaching students with manuscripts has an emotional dimension that is as important as the intellectual dimension: ${ }^{16}$ with manuscripts, students can encounter the writers they have read face to face. This affective growth connects students with writers in an intimate, immediate way that can be difficult to achieve outside of the special collections environment. In one Introduction to Creative Writing class, a first-year student lingered in front of a handwritten letter and manuscript sent to Charles Abbott, founder of the Poetry Collection, by Langston Hughes. He was silent for a long minute before asking incredulously, "Did Hughes actually write this letter?" Visiting the Poetry Collection allowed this student to connect through the artifact to the poet, giving Hughes a new dimension in his mind, not only of someone whose work he admired, but a real person who left behind tangible traces of his poetic life. This moment of simple archival discovery made Hughes immediate and accessible in a way uniquely offered by literary archives, underscoring that visits to special collections can be

16. Marino, "Inquiry-based Archival Instruction," 486. 
a perspective-changing experience for first-year college students as well as for senior researchers. ${ }^{17}$

One series of drafts that lends itself very well to analysis by creative writing students is that for Lorine Niedecker's "I rose from marsh mud." Niedecker, famous for writing in extremely pared-down lines, begins "I rose from marsh mud" with a prose paragraph. To structure their explorations, students use a worksheet for individual and group analysis of the material conditions of the manuscripts and the content, allowing them to discover poetic process as it unfolds. (See the appendix for an example of this worksheet.) I found this to be a useful exercise for undergraduate creative writers not only because it allows them to connect with the writers in their course reading, but because it also allows them to see how a writer approaches the task of writing a poem, dismantling assumptions that a piece of writing is written in order from the first line to the last. Students evaluate their draft individually, describing what it looks like and how Niedecker organizes the "story" of the poem, and become proficient on exactly what Niedecker was doing at the moment in time when she wrote and revised each draft. Then students connect with neighbors who had related drafts: the worksheet asks those responsible for drafts 1 and 2, for instance, to consider how the poem's structure has changed and how this in turn changes the poem. Asking students to identify areas of revision and then analyze how Niedecker worked through her poem allows students to gain insight into the creative revision process, take ownership over writing, and feel an affinity with Niedecker. They come away from the session with the comfort of knowing that everyone revises-a lot-and the satisfaction of having done serious archival analysis. These unique materials can only be seen in a special collections library, encouraging students to feel a sense of pride about the institution and its unique collections.

\section{Conclusion}

While students often enjoy and get a lot out of their visit to special collections, and particularly materials like book objects - they are shocked that they exist and that a library on campus would collect them-it does not always go this way. Some students are dismissive of the poetry objects, closing themselves off to the experience since in their minds these are not books or poetry. This barrier is most often found in Introduction to Creative Writing classes with students who are taking the course as a general education requirement and who have spent relatively little time studying literature. If the professor prepares them in advance for the visit-particularly explaining what they want them to get out of it, and tying the session to the larger goals of the class after their visit—students are more receptive to the experience.

17. First-year students in special collections classrooms can develop "enhanced writing and research skills," as well as affective benefits like an increased passion for history and a sense of common purpose with instructors and fellow classmates. Leslie Waggener, "Milestone, Not Millstone: Archivists Teaching First-Year Seminars," The American Archivist 81, no. 1 (Spring/Summer 2018): 183. 
All of the classes described above are one-shot sessions with no long-term assignment dedicated to the special collections visit. Perhaps the most effective class visits are those that link the class's visit to the final project: for instance, when a professor wanted students to see objects that were both elaborate and easily made so that they could submit for their final portfolio a noncodex project. These students approached the objects with an eye toward direct inspiration, and the book objects showed them the outer limits of the possible. For other students, awash in a sea of avant-garde writers and no long-term motivation to create buy-in, the $\$ 2$ paid by the Poetry Collection in 1968 for an untitled book object made of a ream of office paper (by Aram Saroyan and published by Kulchur Press) was a point of contention and taxpayer dollars wasted. To warm up students in introductory classes, I frontload the session with accordion-fold books, fine press editions, and other fairly familiar books before moving to noncodices, but this strategy can fail with students unreceptive to the larger goals of the course. Preassessment and advanced discussion with the instructor are keys to making sure the class session goes smoothly: identifying the goals the instructor has for the session as they relate to the course as a whole — rather than using this visit as a field trip or break-and incorporating them into the class goes a long way in ensuring that the visit will be a success.

Many of the creative writing instructors I work with — both faculty and $\mathrm{PhD}$ students-are themselves poets, and there has long been a strong connection between the Poetry Collection and the Department of English, particularly its Poetics Program. I hope the longstanding success of this relationship inspires other special collections libraries that do not currently teach creative writing courses that such bridges are worth building and nurturing.

Learning about creative writing in special collections presents students with the opportunity to discover the interplay of form, content, context, and materiality. It encourages students new to the university as well as those further into their careers to take ownership over their research and writing and to understand the process of writing and the contexts for writing communities. By introducing students to chapbooks, book objects, and manuscripts, creative writing classes in special collections allows them to explore and participate in the larger community of writers that is necessarily excised from a course reader or anthology. As creative writing courses become more and more important to English departments as a source of student interest and as course numbers increase, teaching these sessions in special collections helps special collections librarians target new constituents and a wider demographic of users. 


\section{APPENDIX. Two Sample Worksheets}

\section{Chapbook Worksheet}

1. Preliminary exploration

- With the chapbook closed, describe what you see.

- How does the book open? (Vertically? Horizontally? Not at all?)

- When and where was the chapbook published?

- Who wrote it?

- How many poems are printed?

- How much did it cost (if available)?

\section{Material questions}

- What is the chapbook made from/how was it printed? Is there anything distinctive or unusual about the materials?

- How is the chapbook held together (or bound)? (Are there staples, string, folds, or something else?)

\section{Analysis}

- How would the experience of reading this chapbook be different from reading a coursepack/textbook?

- How do you think the form/format of the book changes/contributes to the message of the poem(s)?

\section{Manuscripts Worksheet}

Instructions: Each group member is responsible for one of the drafts of the poem. Read your draft and fill out the individual evaluation part of this worksheet. Then reconvene as a group to answer the final questions.

\section{Individual evaluation}

- What does the poem look like:

o Is it handwritten or typed?

o Is it in stanzas or paragraphs or something else?

o Has the poet written changes on the draft?

- $\quad$ Reading the draft:

o In how many parts does the speaker tell the story? Each stanza (group of lines) makes a distinct episode in telling.

o What is a reading/summary of each part/stanza?

\section{Group Questions}

- How does the poem's structure change from draft 1 to draft 2? How does this change the poem?

- What has Niedecker changed in the first and final stanzas between drafts 2 and 3 ?

- What has Niedecker changed in the first and final stanzas between drafts 3 and 4 ?

- From draft 1 to the "final" draft, what are 3 major changes? 


\section{Training delivered to your library}

ACRL's RoadShow workshops open the door for academic and research libraries to bring high-quality professional development directly to their campus at an affordable cost. These day-long workshops engage participants to learn new skills and strengthen existing competencies to tackle the greatest issues facing the profession today.

Schedule a workshop today! See our available workshops at www.ala.org/acrl/roadshows

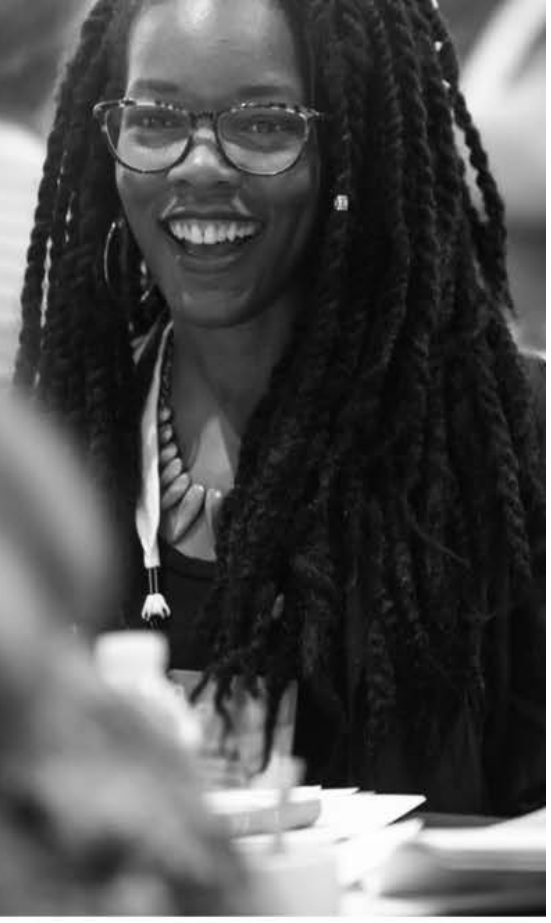

